\title{
IMPLEMENTASI STREAMING DATA DAN ANDROID UNTUK MONITORING POPULASI BURUNG WALET
}

\author{
Muh. Fahmi Rustan ${ }^{1}$, Indra ${ }^{2}$ Anwar $^{3}$ \\ ${ }^{123}$ Informatika, Fakultas Teknik, Universitas Sulawesi Barat \\ Email : ${ }^{1} \underline{\text { MuhFahmi@unsulbar.ac.id }{ }^{2} \text { MuhFuad@unsulbar.ac.id }}$ \\ 3.Anwraputra.1705@gmail.com
}

\begin{abstract}
Abstrak
Alat Implementasi Streaming Data dan Android Untuk Monitoring Populasi Burung Walet ini menitik beratkan kepada para peternak burung walet untuk dapat memonitoring dan mengetahui populasi waletnya didalam gedung. Proses ini dimulai dari deteksi sensor yang dipasang di lubang masuk burung walet dengan sensor diprogram menggunakan arduino uno dan dikoneksikan menggunakan bluetooth untuk ditampilkan di android.
\end{abstract}

\begin{abstract}
Abstrack
Data Streaming and Android Implementation tool for population Monitoring The swiftlet is to monitor the Swallow farmers to distribute and know the population of the fruit in the building. This process is started from detection of sensors that are mounted in a swiftlet inlet with a programmable sensor using Arduino UNO and connected using Bluetooth to be displayed on Android.
\end{abstract}

Kata Kunci : Arduino Uno, Sensor Ultrasonik, Bluetooth

\section{PENDAHULUAN}

Burung walet merupakan burung yang hidup di daerah yang beriklim tropis lembab, dan merupakan burung pemakan serangga yang suka tinggal didalam gua-gua dan rumah-rumah yang cukup lembab, remang-remang dan sampai gelap menggunakan langit-langit untuk membangun sarang dan berkembang biak.

Berdasarkan penelitian para pakar gizi sarang burung walet mengandung glycol protein yang esen nya sangat baik untuk kesehatan tubuh manusia. Dalam penelitian Kementerian Kesehatan RI sarang burung walet mengandung protein, karbohidrat, dan 


\section{JCIS (Journal of Computer and Information System)}

Vol 2 Issue 1, September 2020, Page. 56-68

ISSN (print): 2622-5859 ISSN (online):2622-0881

DOI: $10.31605 /$ jcis.v2i1

lemak. Hal ini mengakibatkan sarang burung walet sangat diminati dan membuat harga sarang burung walet sangat tinggi di pasaran dunia. (1).

Mengingat harga yang sangat tinggi membuat banyak masyarakat Indonesia melakukan pembudidayaan walet dengan membuat rumah atau gedung-gedung bertingkat untuk dijadikan sebagai tempat habitat burung walet sehingga tidak heran jika membuat Indonesia menjadi salah satu Negara penghasil dan pengekspor sarang burung walet terbesar di dunia, yaitu sekitar $60 \%$ kebutuhan pasar di penuhi dari Indonesia.

Populasi burung walet dalam sebuah gedung dapat dihitung meskipun mangandung resiko kesalahan. Ada beberapa teknik menghitung walet di sebuah gedung, yaitu dengan menghitung jumlah sarang, menghitung secara visual, dan menghitung dengan bantuan alat. Perhitungan jumlah sarang dilakukan dengan berinteraksi langsung didalam gedung walet namun tingkat kesalahan perhitungan acak ini cukup besar karena burung walet akan merasa terancam ketika berada didekatnya untuk menghitung sarang. Walet akan merasa takut untuk kembali dan tinggal dalam gedung peternak burung walet. Perhitungan secara visual populasi burung walet dengan cara melakukan melalui perhitungan burung yang masuk ke dalam sebuah gedung pada sore hari dan diulang pada pagi hari. Alat bantu yang digunakan yaitu Checker atau pemeriksaan untuk meminimalkan resiko kesalahan, diperlukan 2-3 orang perhitung.

Tujuan untuk mengetahui jumlah populasi burung walet yang masuk dalam gedung adalah untuk mengetahui perkembangan populasi burung walet apakah populasi burung walet tersebut bertambah atau berkurang jumlahnya yang masuk didalam gedung dan jika populasi burung walet tersebut berkurang dapat disimpulkan adanya suatu gangguan seperti hama, speaker atau twitter yang tidak berfungsi secara normal, dan suhu yang panas juga mempengaruhi berkurangnya populasi burung walet.

Berdasarkan permasalahan di atas, maka akan dibuat suatu alat Implementasi Streaming Data dan Android Untuk Monitoring Populasi Burung Walet berbasis Android sebagai solusi bagi para peternak burung walet dalam mengembangkan populasi burung walet. 
JCIS (Journal of Computer and Information System)

Vol 2 Issue 1, September 2020, Page. 56-68

ISSN (print): 2622-5859 ISSN (online):2622-0881

DOI: $10.31605 /$ jcis.v2i1

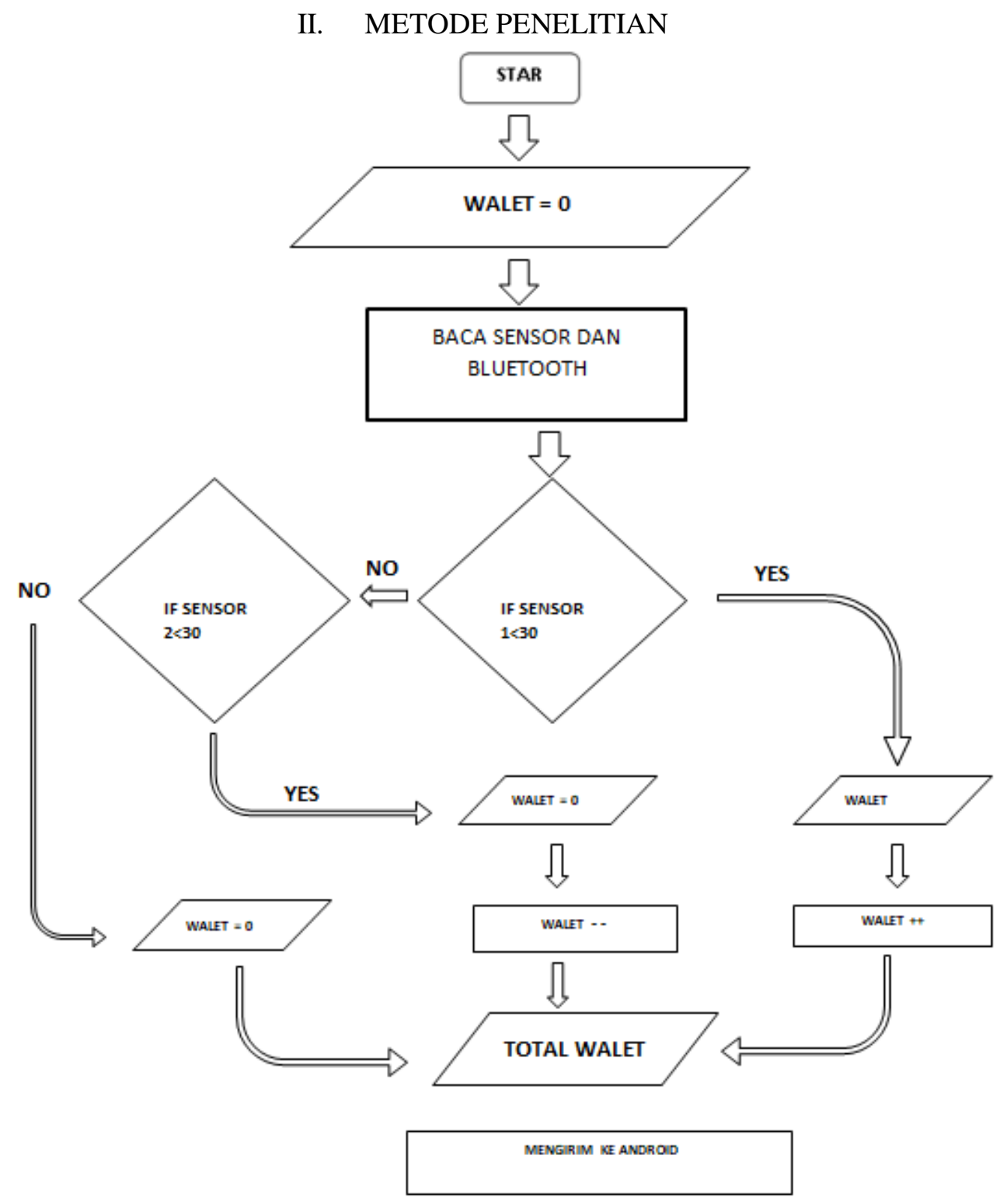

Gambar . 1 Diagram Alir

- Walet sama dengan nol

- Baca sensor dan bluetooth

- Jika sensor 1 membaca yes maka sensor 2 akan membaca no dan akan bertambah +1

- Jika sensor 2 membaca yes maka sensor 1 akan membaca no dan akan kerkurang -1 


\section{JCIS (Journal of Computer and Information System)}

Vol 2 Issue 1, September 2020, Page. 56-68

ISSN (print): 2622-5859 ISSN (online):2622-0881

DOI: $10.31605 /$ jcis.v2i1

\section{HASIL DAN PEMBAHASAN}

Pada tahapan pembuatan sistem akan dijelaskan bagaimana perancangan dari Implementasi Streaming Data dan Android Untuk Monitoring Populasi Burung Walet.

A. Proses Pembuatan Sistem

Pada tahap ini akan dilakukan berbagai macam persiapan komponen yang dibutuhkan untuk membangun sistem. Setelah proses persiapan selesai kemudian komponen-komponen dirangkai menjadi satu. Adapun beberapa komponen yang perlu dipersiapkan untuk mrembuat sistem ini, diantaranya sebagai berikut :
a. Arduino
b. Breadboard
c. Kabel jumper
d. Sensor Ultrasonic
e. Kabel USB
f. Module Bluetooth

B. Hasil Pembuatan Perangkat

Hasil pembuatan perangkat Implementasi Streaming Data dan android untuk Monitoring Populasi Burung Walet dapat dilihat pada gambar berikut :

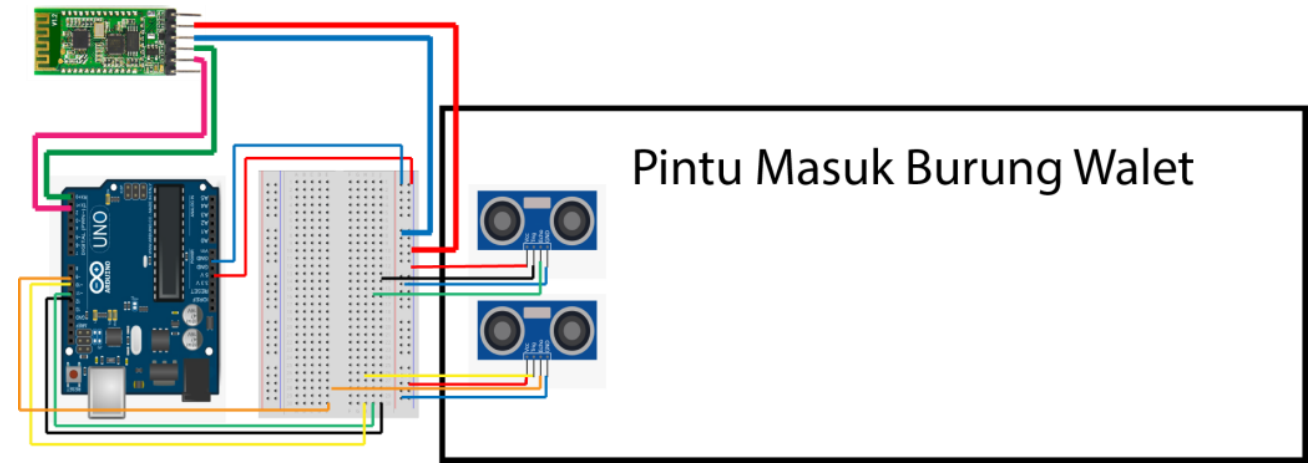

Gambar 2 pembuatan perangkat

- $\quad$ pintu masuk burung walet

- $\quad$ sensor 1 dan 2 pin GND ke pin GND pada arduino uno

- $\quad$ sensor 1 dan 2 pin VCC ke pin VCC pada arduino uno

- $\quad$ sensor 1 pin TRIGGER ke pin 12 arduino uno

- $\quad$ sensor 1 pin ECHO ke pin 11

- $\quad$ sensor 2 pin TRIGGER ke pin 10

- $\quad$ sensor 2 pin ECHO ke pin 9

- bluetooth pin VCC ke pin VCC pada arduino uno

- $\quad$ bluetooth pin GND ke pin GND pada arduino uno 


\section{JCIS (Journal of Computer and Information System)}

Vol 2 Issue 1, September 2020, Page. 56-68

ISSN (print): 2622-5859 ISSN (online):2622-0881

DOI: $10.31605 /$ jcis.v2i1

- $\quad$ bluetooth pin TX ke pin RX pada arduino uno

- bluetooth pin RX ke pin TX pada arduino uno

C. Tampilan Pada Aplikasi Android

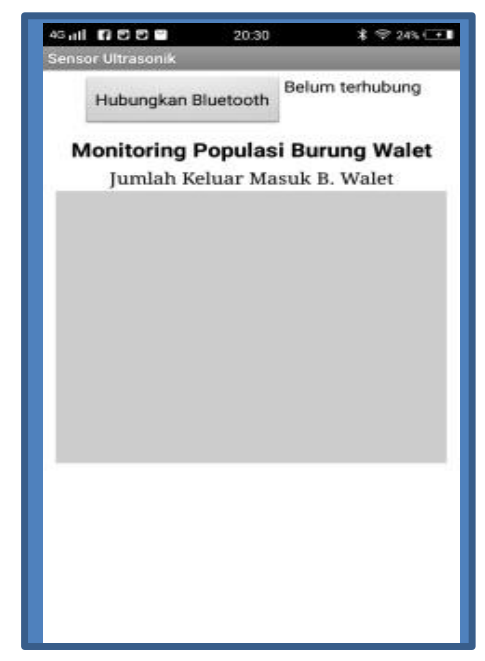

Gambar 3 Tampilan pada aplikasi android

Tampilan pada aplikasi android ini bertujuan untuk menampilkan hasil perhitungan dari perangkat yang telah dibuat.

D. Cara Kerja Alat Dengan Sistem

Sensor ultrasonic membaca objek dan diproses oleh arduino yang sudah diprogram menggunakan aplikasi arduino IDE kemudian hasil baca sensor dikirim melalui bluetooth dari arduino ke aplikasi android yang sudah di buat menggunakan MIT INVENTOR.

E. Analisis Pengujian Sistem

Pengujian perangkat ini dilakukan dengan menguji kerja tiap-tiap bagian perangkat atau rangkain. Rencana pengujian selengkapnya dapat dilihat pada tabel 4.1.

Tabel .1 Tabel Pengujian

\begin{tabular}{|l|l|l|l|}
\hline No & Bagian Uji & Butir Uji & $\begin{array}{l}\text { Jenis } \\
\text { Pengujian }\end{array}$ \\
\hline 1 & Sensor ultrasonic & Mendeteksi objek & Black Box \\
\hline 2 & Bluetooth & Koneksi & Black Box \\
\hline 3 & Android & menampilkan hasil & Black Box \\
\hline
\end{tabular}




\section{JCIS (Journal of Computer and Information System)}

Vol 2 Issue 1, September 2020, Page. 56-68

ISSN (print): 2622-5859 ISSN (online):2622-0881

DOI: $10.31605 /$ jcis.v2i1

Pada tabel .1 adalah tabel pengujian beberapa komponen dengan menggunakan metode black box apakah komponen berfungsi sebagaimana yang diinginkan.

F. Hasil Pengujian

1. Bagian uji sensor

Pengujian perangkat dilakukan dengan menguji validasi sensor. Sensor masuk dan sensor keluar masing-masing dilakukan pengujian untuk menguji tingkat pembacaan sensor ketika ada objek yang melewatinya. Hasil pengujian akurasi sensor masuk didapatkan akurasi $73 \%$ dan $76 \%$ akurasi sensor keluar dari 100 kali percobaan pelemparan dengan sebuah objek yang menyerupai burung walet. Hasil pengujian dilihat pada gambar

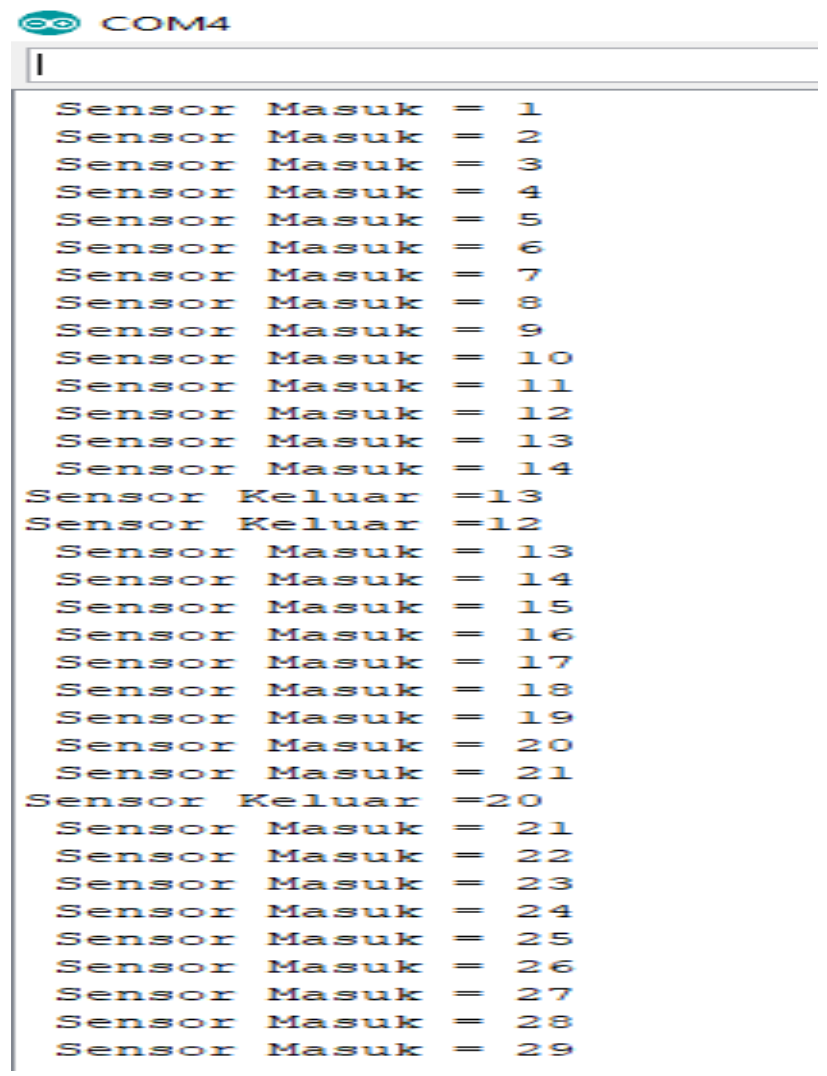

Gambar 4 pengujian objek melewati sensor

Gambar uji coba dengan melemparkan masuk kertas yang menyerupai burung walet. 
JCIS (Journal of Computer and Information System)

Vol 2 Issue 1, September 2020, Page. 56-68

ISSN (print): 2622-5859 ISSN (online):2622-0881

DOI: $10.31605 /$ jcis.v2i1

Tabel 2 pecobaan sensor masuk

\begin{tabular}{|c|c|c|c|}
\hline $\begin{array}{c}\text { Percobaan } \\
\text { ke- }\end{array}$ & Sensor Masuk (TRUE) & Sensor keluar(FALSE) & Validasi \\
\hline 1 & TRUE & FALSE & 1 \\
\hline 2 & TRUE & FALSE & 1 \\
\hline 3 & TRUE & FALSE & 1 \\
\hline 4 & FALSE & FALSE & 0 \\
\hline 5 & TRUE & FALSE & 1 \\
\hline 6 & FALSE & FALSE & 0 \\
\hline 7 & FALSE & FALSE & 0 \\
\hline 8 & FALSE & FALSE & 0 \\
\hline 9 & FALSE & TRUE & 0 \\
\hline 10 & FALSE & FALSE & 0 \\
\hline 11 & FALSE & TRUE & 0 \\
\hline 12 & TRUE & FALSE & 1 \\
\hline 13 & TRUE & FALSE & 1 \\
\hline 14 & FALSE & FALSE & 0 \\
\hline 15 & FALSE & FALSE & 0 \\
\hline 16 & TRUE & FALSE & 1 \\
\hline 17 & TRUE & FALSE & 1 \\
\hline 18 & FALSE & FALSE & 0 \\
\hline 19 & TRUE & FALSE & 1 \\
\hline 20 & TRUE & FALSE & 1 \\
\hline 21 & TRUE & FALSE & 1 \\
\hline 22 & FALSE & FALSE & 0 \\
\hline 23 & TRUE & FALSE & 1 \\
\hline 24 & TRUE & FALSE & 1 \\
\hline 25 & FALSE & FALSE & 0 \\
\hline 26 & TRUE & FALSE & 1 \\
\hline 27 & TRUE & FALSE & 1 \\
\hline 28 & FALSE & FALSE & 0 \\
\hline 29 & TRUE & FALSE & 1 \\
\hline 30 & TRUE & FALSE & 1 \\
\hline 31 & TRUE & FALSE & 1 \\
\hline 32 & FALSE & FALSE & 0 \\
\hline 33 & TRUE & FALSE & 1 \\
\hline 34 & TRUE & FALSE & 1 \\
\hline
\end{tabular}


JCIS (Journal of Computer and Information System)

Vol 2 Issue 1, September 2020, Page. 56-68

ISSN (print): 2622-5859 ISSN (online):2622-0881

DOI: $10.31605 /$ jcis.v2i1

\begin{tabular}{|c|c|c|c|}
\hline 35 & TRUE & FALSE & 1 \\
\hline 36 & TRUE & FALSE & 1 \\
\hline 37 & TRUE & FALSE & 1 \\
\hline 38 & FALSE & FALSE & 0 \\
\hline 39 & TRUE & FALSE & 1 \\
\hline 40 & TRUE & FALSE & 1 \\
\hline 41 & TRUE & FALSE & 1 \\
\hline 42 & TRUE & FALSE & 1 \\
\hline 43 & TRUE & FALSE & 1 \\
\hline 44 & TRUE & FALSE & 1 \\
\hline 45 & TRUE & FALSE & 1 \\
\hline 46 & FALSE & TRUE & 0 \\
\hline 47 & TRUE & FALSE & 1 \\
\hline 48 & TRUE & FALSE & 1 \\
\hline 49 & FALSE & FALSE & 0 \\
\hline 50 & TRUE & FALSE & 1 \\
\hline 51 & TRUE & FALSE & 1 \\
\hline 52 & TRUE & FALSE & 1 \\
\hline 53 & TRUE & FALSE & 1 \\
\hline 54 & TRUE & FALSE & 1 \\
\hline 55 & FALSE & FALSE & 0 \\
\hline 56 & TRUE & FALSE & 1 \\
\hline 57 & TRUE & FALSE & 1 \\
\hline 58 & FALSE & FALSE & 0 \\
\hline 59 & FALSE & FALSE & 0 \\
\hline 60 & TRUE & FALSE & 1 \\
\hline 61 & TRUE & FALSE & 1 \\
\hline 62 & TRUE & FALSE & 1 \\
\hline 63 & TRUE & FALSE & 1 \\
\hline 64 & TRUE & FALSE & 1 \\
\hline 65 & FALSE & TRUE & 0 \\
\hline 66 & TRUE & FALSE & 1 \\
\hline 67 & TRUE & FALSE & 1 \\
\hline 68 & FALSE & FALSE & 0 \\
\hline 69 & TRUE & FALSE & 1 \\
\hline 70 & TRUE & FALSE & 1 \\
\hline 71 & TRUE & FALSE & 1 \\
\hline 72 & TRUE & FALSE & 1 \\
\hline
\end{tabular}


JCIS (Journal of Computer and Information System)

Vol 2 Issue 1, September 2020, Page. 56-68

ISSN (print): 2622-5859 ISSN (online):2622-0881

DOI: $10.31605 /$ jcis.v2i1

\begin{tabular}{|c|c|c|c|}
\hline 73 & TRUE & FALSE & 1 \\
\hline 74 & FALSE & FALSE & 0 \\
\hline 75 & TRUE & FALSE & 1 \\
\hline 76 & TRUE & FALSE & 1 \\
\hline 77 & TRUE & FALSE & 1 \\
\hline 78 & TRUE & FALSE & 1 \\
\hline 79 & TRUE & FALSE & 1 \\
\hline 80 & FALSE & FALSE & 0 \\
\hline 81 & FALSE & FALSE & 0 \\
\hline 82 & TRUE & FALSE & 1 \\
\hline 83 & TRUE & FALSE & 1 \\
\hline 84 & TRUE & FALSE & 1 \\
\hline 85 & TRUE & FALSE & 1 \\
\hline 86 & TRUE & FALSE & 1 \\
\hline 87 & TRUE & FALSE & 1 \\
\hline 88 & TRUE & FALSE & 1 \\
\hline 89 & TRUE & FALSE & 1 \\
\hline 90 & TRUE & FALSE & 1 \\
\hline 91 & FALSE & FALSE & 0 \\
\hline 92 & TRUE & FALSE & 1 \\
\hline 93 & TRUE & FALSE & 1 \\
\hline 94 & TRUE & FALSE & 1 \\
\hline 95 & TRUE & FALSE & 1 \\
\hline 96 & TRUE & FALSE & 1 \\
\hline 97 & FALSE & FALSE & 0 \\
\hline 98 & TRUE & FALSE & 1 \\
\hline 99 & TRUE & FALSE & 1 \\
\hline 100 & TRUE & FALSE & 1 \\
\hline \multicolumn{3}{|c|}{ Total Berhasil } & 73 \\
\hline \multicolumn{3}{|c|}{ Total tidak berhasil } & 27 \\
\hline
\end{tabular}

Gambar tabel percobaan sensor masuk dengan 100 kali percobaan yang menghasilkan total berhasil 73 dan total yang error sejumlah 27 kali. 
JCIS (Journal of Computer and Information System)

Vol 2 Issue 1, September 2020, Page. 56-68

ISSN (print): 2622-5859 ISSN (online):2622-0881

DOI: $10.31605 /$ jcis.v2i1

2. Bagiam uji module bluetooth

Pengujian dilakukan dengan setting pada bluetooah sehingga dapat terkoneksi perangkat yang dibuat dengan android.

Tabel 1.1 tabel pengujian bluetooth

\begin{tabular}{|c|c|l|}
\hline No & Jarak (Meter) & \multicolumn{1}{|c|}{ Hasil } \\
\hline 1 & $1 \mathrm{~m}$ & {$[\sqrt{ }]$ Berhasil } \\
& & {[] Tidak Berhasil } \\
\hline 2 & $2 \mathrm{~m}$ & {$[\sqrt{]}$ Berhasil } \\
{[] Tidak Berhasil }
\end{tabular}




\section{JCIS (Journal of Computer and Information System)}

Vol 2 Issue 1, September 2020, Page. 56-68

ISSN (print): 2622-5859 ISSN (online):2622-0881

DOI: $10.31605 /$ jcis.v2i1

\begin{tabular}{|l|c|l|}
\hline 19 & $19 \mathrm{~m}$ & $\begin{array}{l}{[\sqrt{ }] \text { Berhasil }} \\
{[] \text { Tidak Berhasil }}\end{array}$ \\
\hline 20 & $20 \mathrm{~m}$ & $\begin{array}{l}{[\sqrt{ }] \text { Berhasil }} \\
{[] \text { Tidak Berhasil }}\end{array}$ \\
\hline
\end{tabular}

Pengujian bluetooath dilakukan dengan menguji koneksi bluetooth pada aplikasi android sehingga dapat menampilkan data-data sensor yang dikirim melalui bluetooth. Hasil percobaan didapatkan jarak maksimal data sensor terkirim dengan baik pada jarak 11 meter dengan tidak ada halangan.

\section{KESIMPULAN DAN SARAN}

A. Kesimpulan

Kesimpulan yang dapat diambil berdasarkan hasil perencangan dan pengujian dengan perangkat Implementasi Streaming Data dan Android Untuk Monitoring Populasi Burung Walet menggunakan dua buah Sensor Ultrasonik sehingga pemilik sarang walet dapat menghitung populasi walet dalam sarang yang dibuat dan mengukur kelembaban udara sarang walet sehingga produktivitas walet dapat di kontrol.

B. Saran

Adapun saran-saran yang dapat penulis berikan yaitu :

1. Sistem monitoring populasi walet yang dibuat belum menggunakan internet sehingga aplikasi android yang digunakan sebagai media penerima informasi tidak dapat berada pada jangkauan.

2. Perlu adanya pengemabangan lebih lanjut terhadap sistem monitoring sarang walet sehingga dapat berjalan sesuai dengan keinginan.

\section{DAFTAR PUSTAKA}

1. analisis profil makronutrien dan kandungan nitrit pada bagian sarang burung walet .

Monang Sihombing, Dhanang Puspita Mayer Tinting Sirendeng. 2018, "Inovasi

Pangan Lokal Untuk Mendukung Ketahanan Pangan" Universitas Mercu Buana

Yogyakarta - Yogyakarta, 28 April 2018, hal. 1 -6.

\section{SISTEM MONITORING PENGUMPULAN GETAH KARET BERBASIS SMS GATEWAY PADA}

PETANI KARET DI DESA SURYA ADI KABUPATEN OKI PROVINSI SUMATERA SELATAN.

Maya Amelia, Maya. 2016, JURNAL ILMIAH INFORMATIKA GLOBAL.

3. INTERNET OF THINGS, SEJARAH, TEKNOLOGI DAN PENERAPANNYA : REVIEW. Junaidi, Apri. 2015, Jurnal IImiah Teknologi Informasi Terapan, hal. 62-66. 


\section{JCIS (Journal of Computer and Information System)}

Vol 2 Issue 1, September 2020, Page. 56-68

ISSN (print): 2622-5859 ISSN (online):2622-0881

DOI: $10.31605 /$ jcis.v2i1

4. Analisis Big Data Berbasis Streaming Processing Menggunakan Apache Spark. Sitepu, Harry, Tumbe, Claudia Zefanya dan Hutagalung, Maclaurin. 2019, Jurnal Telematika, hal. 27-31.

5. IMPLEMENTASI APLIKASI RUMAH PINTAR BERBASIS ANDROID DENGAN ARDUINO MICROCONTROLLER. Muslihudin, Muhamad, et al., et al. 2018, Jurnal Keteknikan dan Sains (JUTEKS) - LPPM UNHAS, hal. 23-31.

6. PERANCANGAN ALAT BANTU PENGUKURAN JARAK DALAM GUA BERBANTUAN ARDUINO MENGGUNAKAN SENSOR ULTRASONIK. Busran dan Ferdiansyah, Egi. 2017, Jurnal TEKNOIF, hal. 36-40.

7. PROTOTYPE SMART HOME DENGAN MODUL NODEMCU ESP8266 BERBASIS INTERNET OF THINGS (IOT). Lusita Dewi, Nuru Hidayati, Rohmah, Mimin F. dan Zahara, Soff. 2016, Prototype Smart Home Dengan Modul Nodemcu ESP8266 Berbasis Internet of Things (loT), hal. 1-9.

8. IDENTIFIKASI HABITAT DAN PRODUKSI SARANG BURUNG WALET (Collocalia fuciphaga) DI KABUPATEN LAMPUNG TIMUR. Ayuti, Turaina, Garnida, Dani dan Asmara, Indrawati Yudha. 2016, Identifikasi Habitat dan Produksi Sarang Burung Walet, hal. 1-5.

10. SISTEM KONTROL PENDINGIN RUANGAN MENGGUNAKAN ARDUINO WEB SERVER DAN 9. IMPLEMENTASI IOT DALAM RANCANG BANGUN SISTEM MONITORING PANEL SURYA BERBASIS ARDUINO. Rohman, Fadlur dan lqbal, Mohammad. 2016, Pros iding SNATIF, hal. 189-196.

EMBEDDED FUZZY LOGIC DI PT. INOAC POLYTECHNO INDONESIA. Fikriyah, Lulu dan Rohmanu, Ajar. 2018, Jurnal Informatika SIMANTIK, hal. 21-27.

11. Akhmad Zainuri, Ungul Wabawa Eka Maulana. 2015, Implementasi Bluetooth HC-05 untuk Memperbarui Informasi Pada Perangkat Running Text BerbasisAndroid.

12. I Wayan Boby Astagina Naghi, Subriansyah Rizqika Akbar Barlian Henryranu. Implementasi Sistem Pervasive Pada Smart Home Berbasis Bluetooth Versi 4.0 Menggunakan Modul BLE HM-10 dan Sensor. 